\title{
State-Owned Enterprises in India: Restructuring and Growth
}

\author{
SUSHIL KHANNA
}

\begin{abstract}
Economic reforms in India are often hailed as the march of private enterprise, unshackled from bureaucratic control. Though it is true that the Indian growth story is led by private capital, reforms have also unleashed a resurgent public sector in the Indian economy, with a significant contribution to investment and growth in India. This article looks at the political economy of SOE reforms, their partial privatization and restructuring, with enhanced autonomy as the key factors that have shaped a more dynamic SOE sector, at least amongst those controlled by the central government. As India moved to market-based prices and incentives, and better contract enforcements, central government SOEs (CSOEs) have substantially enhanced their profitability, investments and growth. As far as manufacturing SOEs are concerned, their profitability and efficiency is superior to private firms, while the performance of CSOEs in services has been rather poor.
\end{abstract}

Keywords: India, state-owned enterprises, economic reforms, privatization

\section{Introduction}

The programme of reforms, economic liberalization and deregulation since 1991 marks a turning point in the history of modern India's economic development. It signals a decisive shift towards a neo-liberal strategy of development, long advocated by multilateral institutions such as the International Monetary Fund and the World Bank. Whether this shift was a result of the conditions imposed by these institutions when India, confronted with the problem of acute balance of payments in 1990-91, approached them for assistance, is immaterial today. This is because over the period of the last two decades there has been strengthening of resolve by domestic lobbies that have long favoured deregulation and privatization.

The state-owned enterprises (SOEs) have long dominated the industrial and commercial sectors. They have experienced a chequered history, and today face unprecedented pressures and threats with dramatic changes in the business environment that in many ways 
have few parallels in the world. Unlike China, where the private sector was largely absent and hence unable to influence policies that shaped competition, the Indian SOEs faced unprecedented pressures as the political economy shifted decidedly in favour of large business, largely controlled by business families or groups. This shift means that private competitors could now influence 'controllers', usually politicians and bureaucrats who shape policy as well as regulate and approve further investment and expansion of SOEs.

This article looks at the restructuring of Indian SOEs under the new regime of liberalization and deregulation. It traces the shifts in policy over the last two decades, including the period of privatization and the response of the SOEs to these policy shifts. Despite the policy shift in favour of the private sector, there are several sectors of the economy where SOEs continue to play a major role driving growth and accumulation. They have restructured and changed their governance structures along with greater autonomy granted to larger and profitable units. In addition, the Indian SOEs, despite their declining weight in the economy, continue to dominate major sectors of the economy. This article responds to the suggestion that privatization and the resulting so-called 'efficiency' of resource use would have accelerated growth. We trace the important role that state-owned enterprises have played in accumulation and acceleration of the rate of growth in India since 2004, along with their strategic role in acting as a countervailing force to private capital, both domestic and foreign.

\section{Planned Development and the Role of SOEs}

\section{The Public Sector in the Indian Economy}

Even before India achieved its formal independence from British rule, the emerging political and economic elites had envisaged a major role for the public sector. With a weak bourgeoisie, limited domestic savings, a tiny capital market and a small banking sector, and a global economy disrupted by long wars, the consensus was that the emergent state should play a major role in fostering economic development and industrialization through a process of planning (Chattopadhyay 1987). Very early, India launched its fiveyear plans, modelled on the pattern of the USSR and China, with emphasis on fiscal measures to raise resources for investment and state-led investment planning. 
Thanks to this primacy given to the public sector, it soon emerged as the main site of investment in the economy. Due to this, the public sector has historically been the driver of economic growth in the Indian economy. From the period of the Second Five-Year Plan (1956), the public sector has accounted for about 45-50 per cent of gross capital formation (Table 1). Despite the bulk of the economy being in the private sector,

TABLE 1: India: Savings and Gross Domestic Capital Formation

\begin{tabular}{|l|c|c|c|c|c|c|c|c|}
\hline Savings and GCF as per cent of GDP at Current Market Prices (per cent) \\
\hline Year & Household Sector & Private Corp. Sector & Public Sector & \multicolumn{1}{l|}{ Total } \\
\hline & Savings & GCF & Savings & GCF & Savings & GCF & Savings & GCF \\
\hline \multicolumn{8}{|c|}{ As per cent of GDP at Current Market Price } \\
\hline $1955-56$ & 8.98 & 5.10 & 1.21 & 2.10 & 2.09 & 5.10 & 12.29 & 12.30 \\
\hline $1960-61$ & 6.53 & 3.91 & 1.61 & 3.29 & 3.07 & 7.23 & 11.21 & 14.43 \\
\hline $1965-66$ & 8.60 & 4.77 & 1.45 & 2.66 & 3.64 & 8.70 & 13.68 & 16.13 \\
\hline $1970-71$ & 9.45 & 6.49 & 1.45 & 2.39 & 3.30 & 6.71 & 14.21 & 15.59 \\
\hline $1975-76$ & 10.88 & 6.23 & 1.29 & 2.78 & 4.69 & 9.78 & 16.86 & 18.79 \\
\hline $1980-81$ & 12.88 & 6.96 & 1.61 & 2.65 & 4.00 & 8.94 & 18.49 & 18.55 \\
\hline $1985-86$ & 13.13 & 6.54 & 1.93 & 5.53 & 3.92 & 11.40 & 18.98 & 23.47 \\
\hline $1990-91$ & 18.40 & 9.68 & 2.66 & 4.49 & 1.77 & 9.98 & 22.82 & 24.16 \\
\hline $1995-96$ & 16.87 & 8.00 & 4.96 & 10.40 & 2.59 & 8.20 & 24.42 & 26.59 \\
\hline $2000-01$ & 21.64 & 11.40 & 3.86 & 5.19 & -1.75 & 6.88 & 23.74 & 24.16 \\
\hline \multicolumn{7}{|c|}{ (Base Year: 1999-2000) } \\
\hline $2005-06$ & 23.17 & 11.80 & 7.49 & 13.47 & 2.42 & 7.91 & 33.08 & 34.30 \\
\hline $2008-09$ & 22.63 & 12.20 & 8.44 & 12.71 & 1.44 & 9.40 & 32.50 & 35.59 \\
\hline
\end{tabular}

\begin{tabular}{|l|c|c|c|c|c|c|c|c|c|}
\hline \multicolumn{1}{|c|}{ Savings and GCF as per cent of Total } \\
\hline Year & Household Sector & Private Corp Sector & \multicolumn{1}{|l|}{ Public Sector } & \multicolumn{1}{l|}{ Total } \\
\hline & Savings & GCF & Savings & GCF & Savings & GCF & \multicolumn{1}{|c|}{ Savings } & GCF \\
\hline \multicolumn{8}{|c|}{ 1999-2000) } \\
\hline $1955-56$ & 73.08 & 41.41 & 9.88 & 17.10 & 17.04 & 41.49 & 100 & 100 \\
\hline $1960-61$ & 58.20 & 27.07 & 14.40 & 22.77 & 27.41 & 50.12 & 100 & 100 \\
\hline $1965-66$ & 62.85 & 29.59 & 10.57 & 16.49 & 26.58 & 53.95 & 100 & 100 \\
\hline $1970-71$ & 66.52 & 41.60 & 10.23 & 15.35 & 23.25 & 43.05 & 100 & 100 \\
\hline $1975-76$ & 64.55 & 33.14 & 7.63 & 14.81 & 27.82 & 52.04 & 100 & 100 \\
\hline $1980-81$ & 69.66 & 37.51 & 8.70 & 14.30 & 21.64 & 48.19 & 100 & 100 \\
\hline $1985-86$ & 69.19 & 27.88 & 10.16 & 23.55 & 20.64 & 48.57 & 100 & 100 \\
\hline $1990-91$ & 80.60 & 40.08 & 11.66 & 18.59 & 7.74 & 41.33 & 100 & 100 \\
\hline $1995-96$ & 69.08 & 30.07 & 20.33 & 39.09 & 10.60 & 30.84 & 100 & 100 \\
\hline $2000-01$ & 91.15 & 47.17 & 16.24 & 21.46 & -7.39 & 28.47 & 100 & 100 \\
\hline \multicolumn{8}{|c|}{ (Base Year: 2004-2005) } \\
\hline $2005-06$ & 70.04 & 34.41 & 22.63 & 39.27 & 7.33 & 23.06 & 100 & 100 \\
\hline $2008-09$ & 69.63 & 34.27 & 25.96 & 35.70 & 4.42 & 26.42 & 100 & 100 \\
\hline
\end{tabular}

Source: India. 2011. Reserve Bank, Handbook of Statistics on Indian Economy, Mumbai 
the private corporate sector has been a minor site of accumulation. Until the early 1980s, the private corporate sector accounted for about 20 per cent of total capital formation (less than 3 per cent of GDP). Until very recently, the household sector (including medium and small enterprises, largely in the unorganized sector) accounted for 30-40 per cent of total Indian capital formation.

In terms of savings, the bulk of the savings (about 70 per cent of the total) was provided by the household sector. This was followed by the public sector, while the private corporate sector provided about 10 per cent of the savings (approximately 2-4 per cent of GDP).

The 1980s was a decade of growing fiscal crisis as the government began to run larger fiscal deficits, with a significantly large revenue deficit by 1990. With this, 'public administration' (surplus from taxes after revenue expenditure was met) that provided substantial savings several-fold larger than 'non-departmental enterprises' (in other words, state-owned enterprises), now became a drain on the savings from such enterprises. This increasing deficit of the 'public administration' was accompanied by growing efficiency and increasing savings and investment in the 'non-departmental enterprises' (that is, SOEs) (Table 2).

As India embarked on its neo-liberal policies by dismantling planning and shifting to the market and private sector to propel growth,

TABLE 2: India: Structure of National Savings at Current Prices $(2004-2005 \text { Series })^{1}$

\begin{tabular}{|c|c|c|c|c|c|}
\hline \multirow[b]{2}{*}{ Year } & \multirow[b]{2}{*}{$\begin{array}{l}\text { House- } \\
\text { holds }\end{array}$} & \multirow[b]{2}{*}{$\begin{array}{c}\text { Private } \\
\text { Corporate }\end{array}$} & \multicolumn{2}{|c|}{ Public Sector } & \multirow[b]{2}{*}{ Total GDS ${ }^{3}$} \\
\hline & & & $\begin{array}{c}\text { Public } \\
\text { Authorities }\end{array}$ & SOEs $^{2}$ & \\
\hline $1955-1956$ & 1,041 & 134 & 220 & 27 & 1,422 \\
\hline $1960-1961$ & 1,226 & 281 & 509 & 63 & 2,079 \\
\hline $1965-1966$ & 2,596 & 405 & 900 & 185 & 4,086 \\
\hline $1970-1971$ & 4,531 & 672 & 1220 & 397 & 6,821 \\
\hline $1975-1976$ & 9,790 & 1,083 & 3299 & 893 & 15,066 \\
\hline $1980-1981$ & 18,116 & 2,339 & 4278 & 1,857 & 26,590 \\
\hline $1985-1986$ & 36,666 & 5,426 & 3783 & 7,539 & 53,414 \\
\hline 1990 - 1991 & 108,603 & 15,164 & $-6,169$ & 16,810 & 134,408 \\
\hline $1995-1996$ & 198,585 & 59,153 & $-6,493$ & 38,019 & 289,265 \\
\hline $2000-2001$ & 463,750 & 81,062 & $-90,644$ & 61,377 & 515,545 \\
\hline $2005-2006$ & 868,988 & 277,208 & $-58,279$ & 147,234 & $1,235,151$ \\
\hline $2010-2011$ & $1,749,311$ & 602,464 & $-99,212$ & 229,367 & $2,481,931$ \\
\hline
\end{tabular}

Notes: 1 In crores (1 crore = Rs. 10 million); 2 SOEs are referred to as 'non-departmental enterprises' in the original resource; 3 GDS = Gross Domestic Savings

Source: CSO, National Accounts Series, as reproduced in EPW Research Foundation, National Income Database. 
the Indian state embarked on a policy of lowering tax rates, cutting subsidies and reducing investment in sectors reserved for the public sector, while facilitating the entry of the private sector into such areas. It has also encouraged opening up the financial sector and capital market to global investors, thus ending the public sector's monopoly over the financing of private enterprises.

As a result, the rate of growth of the private corporate sector has accelerated since the policy of liberalization began in 1991. By 1995, the private sector had overtaken both the public sector as well as the household sector in terms of investment and capital formation. This expansion in the private corporate sector's share has been entirely at the expense of the public sector, where capital formation has fallen from 49 per cent of total investment to about 25 per cent (Table 1). Not only has the private sector emerged as an important driver of increasing accumulation, its savings, too, have shown a sharp increase in the last ten years. These have jumped from about 3.5 per cent of GDP to 8-9 per cent of GDP.

\section{State-Owned Enterprises in Indian Development}

To understand why and how the SOEs in India play such a significant leading role, it is important to recall the Indian industrialization strategy since the 1950s. It was the Industrial Policy Resolution (1956) that reserved the commanding heights of the economy for state enterprises. Though the private sector was allowed to play its role and private property was protected by the Constitution, the areas opened to it for investment were limited. Since the time of India's independence in 1947, enterprises in public utilities and infrastructure, including the railways, ports, airports and telecommunication and power units had largely been in the public sector. The Industrial Policy Resolution even earmarked several basic and capital good sectors exclusively for the public sector. In fact, the private enterprises already in existence in these sectors (reserved for SOEs) could continue only with the state's permission and were to be gradually nationalized. However, the bulk of consumer goods sectors of the economy, as well as production of several intermediate goods such as cement, were opened to the private sector.

The key role assigned to the SOEs in the industrialization strategy was to help India achieve economic self-reliance. The basic objectives of the enterprises were: 1) to build infrastructure for economic devel- 
opment and promote industrialization; 2) to promote employment and balanced regional development; 3 ) to create a self-reliant economy through import substitution and develop the capacity to export; 4) to generate surpluses for development by earning suitable returns; and 5) to prevent concentration of private economic power.

At the beginning of the First Five-Year Plan (1952), the country had only five SOEs, with a total investment of 290 million rupees (Rs.) (approximately US\$60 million, at the 1955 exchange rate). By the Second Five-Year Plan, which coincided with the announcement of the Industrial Policy of 1956, a spate of new SOEs was being established in several core and basic industries. Units producing steel, heavy engineering, fertiliser, electricity generation equipment, machine tools, etc. were set up, several of them with technological and financial assistance of the Soviet Union and other East European countries. Subsequently, in the 1970s, the government nationalized the coal industry, large commercial banks and all insurance companies. It also took over several firms in the private sector that were facing bankruptcy and had closed down or were on the verge of closure.

Though the most significant SOEs were established by the central (federal) government (referred to hereafter as CSOEs), a large number of enterprises were established by state (provincial) governments (SSOEs), including many in the joint sector where the private partners held up to 49 per cent of the shares. A few units were even established by municipalities or jointly by state and central governments.

In the 1990s (at the end of the Seventh Five-Year Plan), when the Indian government launched the programme of deregulation and liberalization, the number of CSOEs had increased to 244 (excluding the commercial banks and insurance companies), up from five units four decades before. By 2005-2006, these had declined to 239 due to the disinvestment and privatization of a few leading CSOEs by the government led by the Bharatiya Janata Party (BJP).

By the early 1990s, many key sectors of the economy were dominated by mature public enterprises that had successfully expanded production, opened up new areas of technology, and substituted imports in an array of capital goods sectors, with technical competence that enhanced India's ranking in terms of industrialization, with a large pool of trained workers, along with technical skills, especially in chemical and manufacturing industries. 


\section{Deregulation and Liberalization and the Changing Role of SOEs}

In the 1990s, as the policy of liberalization and deregulation gathered pace, along with policies to promote increasing integration of the Indian economy with the global economy, SOEs were robbed of their historic role. A new industrial policy was announced on 24 July 1991, which opened up most sectors of the economy to private entry and investment. Simultaneously, foreign investment was welcomed. Foreign-owned enterprises could now hold 51 per cent or more in the enterprises set up in the country. Foreign Institutional Investors (FIIs) were allowed to invest in Indian stock exchanges and restrictions on mergers and acquisitions were abolished. The new industrial policy announced that the exclusive role of the public sector was to be limited to a few strategic sectors.

With the shift in the public policy towards liberalization and deregulation, the business environment of Indian SOEs underwent a radical change. The most significant of these changes are:

a) Free entry to private sector firms in industries reserved exclusively for SOEs. The most significant of industries affected by this policy were telecommunications, petroleum (from extraction to refining and marketing), electricity generation and distribution, several basic goods industries like steel, aluminium, etc., mining and air transportation.

b) Disinvestment of a small part of the government's shareholding (while still holding majority stocks) and listing SOEs on the stock exchanges.

c) Ensuring that the listed SOEs follow the stock exchanges' listing requirements including disclosure and governance regulations, appointment of independent directors, independent remuneration and audit committees, etc.

d) Withholding or withdrawing budgetary support to loss-making ('sick') SOEs. Subsequently, sick SOEs were denied permission to revise wages and salaries.

e) Loss-making SOEs were to be encouraged to lay off workers to seek commercial viability, failing which, they were to be closed down or privatized.

The radical shift in public policy was based on an ideological shift towards market-based reforms and neo-liberal ideology. The clamour for large-scale privatization from foreign investors and several Indian and foreign advisors became pronounced. Privatization was not directly 
stated in the government policy announcement, but was more clearly articulated by the advisers appointed by the Indian government (see India 1993; Bhagwati \& Srinivasan 1993; and Bhandari \& Goswami 2000). SOEs were assumed to be 'immensely inefficient'. These advisers also called for renouncing the creation of new SOEs in areas where private sectors were willing to invest. Bhagwati and Srinivasan (1993), however, insisted that the sale of fractional equity on the stock exchange did not adequately signal to SOE managers that they should improve their efficiency and productivity and they favoured 'privatization that transfers control and management to the private sector' (Bhagawati \& Srinivasan 1993: 50).

The advice of the World Bank (Seabright 1993) and neo-liberal economists (Bhagawati \& Srinivasan 1993; Bhandari \& Goswami 2000) was to restructure the SOEs with the aim of complete privatization. Yet the actual evolution of the policy faced opposition and resistance and took many years. The policy of complete privatization was carried out only when a change in the government brought the right-wing BJP to power.

The sudden shift in the public policy and the business environment of state enterprises had the potential to undermine the profitability and economic viability of most enterprises. It was widely believed that the SOEs were inefficient and used resources badly and subjecting them to market forces and competition would help in restructuring them. With adequate support from the government and the help of the National Renewal Fund established with the assistance of the World Bank, it would help minimize the human cost of SOE restructuring. The government encouraged all the SOEs, but especially the loss-making enterprises, to reduce their workforce wherever possible through a scheme of 'voluntary retirement'. It is estimated that approximately half a million workers were forced to leave. ${ }^{1}$

The reforms of the public sector have gone through three distinct phases (Dhameja 2006), reflecting the changing political coalitions and underlying political economy.

First Phase of Reforms (1992-1998) Here the Congress Party government embarked on a policy of divesting up to 20 per cent of shares to mutual funds (fractional equity sale), the general public and workers. From 19931994, foreign institutional investors (FIIs) were also allowed to bid for shares. However, despite the recommendation of the Rangarajan Committee (India1993) to divest up to 74 per cent of shares in non-strategic areas, only one CSOE was privatized, the automobile company Maruti 
was sold to the Japanese partner Suzuki. Few CSOEs were sold to other SOEs in the same sector. Thus, the petroleum marketing company IBP was sold to IOC Ltd. (both CSOEs), which has a dominant position in the petroleum refining and marketing sector.

Along with the new industrial policy, the government decided to review the portfolio of investment by SOEs, with the view to focus on enterprises in strategic, high-technology sectors and on essential infrastructure. Moreover, restrictions on the private sector in areas that so far had been exclusively reserved for state investment were withdrawn. Simultaneously, the SOEs were also to be allowed to enter any sector that was not earlier reserved for it.

In addition, the government announced that SOEs that were chronically sick and could not be turned around were to be referred to the Board for Industrial and Financial Restructuring (BIFR) or similar high-level institutions to be created for this purpose. A social security mechanism to protect the interest of workers likely to be retrenched or laid off was to be developed. The government also announced that to raise resources as well as encourage wider public participation, a part of the government's shareholding in SOEs was to be offered to mutual funds, financial institutions, workers and the public at large.

The boards of the SOEs were to be made more professional and given greater powers. Soon the government announced a list of companies, which were designated as 'Nav Ratnas' ('New Jewels'), where the company board would have substantially enhanced powers to undertake investments, acquire assets and companies in India and abroad and enjoy greater autonomy. Such enterprises were usually the better managed and more profitable ones, often with a dominant position in a sector or a branch of industries. Over the years, the list of such enterprises was expanded with graded levels of autonomy. ${ }^{2}$

Second Phase of Reforms (1998-2004) The government was now headed by a coalition led by the right-wing Bharatiya Janata Party, which decided on large-scale privatization or strategic sale of a controlling stake to private parties as well as to better performing SOEs. In all, a dozen SOEs were privatized during this period and in two cases the government controlling block was sold to other SOEs in the same sector. The government realized a total of Rs. 63.5 billion from such strategic sales. Amongst the major SOEs privatized were Indian Petro-chemicals Limited, VSNL, which had a monopoly on long-distance telecommunications traffic and was the largest provider of internet services, Bharat Aluminium, along with 18 hotels run by the Indian Tourism Development Corporation. In 
addition, the government stake of 4.5 per cent in the Gas Authority of India Ltd. was sold to ONGC and IOC, both of which were large and cash-rich SOEs in the petroleum sector

Third Phase of Reforms (2004-2010) Once again the government was led by the Congress Party and until 2009 the government depended on the communist parties for support. During this period, privatization was discontinued. Under pressure from the communist parties and trade unions, the government agreed to make serious efforts to revive the underperforming or 'sick' CSOEs. It appointed a Board for Reconstruction of Public Sector Enterprises (BRPSE) with a mandate to undertake financial restructuring and revival of sick SOEs. During this period, BRPSE recommended restructuring 60SOEs, the closure of two and the strategic sale of two other enterprises.

In 1997, the Disinvestment Commission pronounced that the government had failed to provide a 'level playing field' to SOEs. It stated that though the private sector had been granted full freedom to enter any industry, add capacities, enter sectors hitherto reserved for SOEs (such as telecommunications, generation and distribution of electricity, petroleum extraction and refining), the public sector faced several handicaps while competing against the private enterprises. The Commission felt that despite the promise of greater autonomy to SOEs in the policy statements, they still had to obtain multi-level and time-consuming approval for decisions and were accountable to multiple agencies with varying mandates. 'This lack of autonomy has created a somewhat unequal playing field for the PSUs (SOEs) in an increasingly competitive environment' (India 1997: 7).

In response to these criticisms, as well as the reversal of the BJP's privatization programme, the Congress Party-led government appointed in 2004 a committee under Arjun Sengupta to look at ways of granting 'full managerial and commercial autonomy' to central government SOEs, with a view to enhancing their ability to respond to market-based competition from private sector firms. The committee recommended sweeping changes in the relationship between the controlling ministry and the SOEs, since it felt that the ministries' numerous and detailed interventions in routine operations of SOEs was a serious erosion of their autonomy to carry out business. It wanted all major decisions, both strategic and operational, to be under the control of the board of directors, where at least half of the board members would be independent directors. In case a ministry wanted to issue any instructions to an SOE, it should issue a 'Presidential Decree', which would require the 
approval of the entire cabinet. It also sought to insulate SOEs from 'Parliamentary interference' that could require SOEs to reveal commercially sensitive information that could help its private sector competitors. It recommended a 'negative list' where the government would have no say, including decisions on pricing, distribution, import/export, appointment of dealers and agents and promotion of employees. The powers of Nav Ratnas to set up joint ventures or invest were to be enhanced. In addition, it recommended sector-specific supervisory bodies to review the performance of SOEs (India 2005).

Despite the break with the communist parties in 2009 and the formation of a new Congress-led coalition government, the policy of privatization has not been resumed. The government continues to sell small amounts of shares in the SOEs listed on the stock exchange, with a view to raise resources to bridge the government's rising deficit. In recent years, it has also asked SOEs to increase the rate of dividend.

To sum up, despite strident demands from many economists and multilateral institutions, the Indian government has found it difficult to carry out any further privatization or strategic sale of CSOEs. However, some SSOEs (SOEs owned by provincial governments) have been sold in some states. The central government, however, has continued its policy of selling shares held by the government in enterprises to mutual funds, financial institutions, workers and the public at large, but the sales (of fractional equity) have not resulted in change of control or privatization

\section{Restructuring and Reconstitution of the CSOEs and SOEs after Reforms}

Why did the successive governments in India fail to undertake largescale privatization? Why did the BJP government fail to carry out its mandate to sell all SOEs in all industries except units in the defence and the atomic energy sectors as the Disinvestment Commission had suggested? We turn to the political economy of the reforms programme.

First, though the successive governments espoused their commitment to the reforms and privatization, there is overwhelming evidence that the majority of voters were opposed to the economic reforms in general and privatization in particular. ${ }^{3}$ Second, the governments that carried out these reforms faced resistance from trade unions and middle class consumers, who were afraid of increased prices of goods, services, etc. Third, successive governments were defeated in elections (India had five governments during the 1991-1999 period), forcing the political parties 
to be wary of the electoral costs of large-scale privatization. Fourth, several cases of privatization in India by the BJP invited sharp criticism, especially when assets sold by the government were re-sold by the acquiring parties at substantially higher prices. There were allegations of large-scale corruption and the sale of valuable assets at low prices. Lastly, given the large weight of SOEs in industrial assets and sales, large-scale privatization could result in economic dislocation, jeopardizing growth. Indeed, as it became clear to the political establishment that privatization was fraught with high risk, a new role for SOEs began to be envisaged. This was also possible due to significant changes in the governance structures and autonomy to managers, as well as substantial improvement in the profits and growth by SOEs.

\section{India in the New Millennium: Accumulation, Growth and State-Owned Enterprises}

According to the neo-liberal folklore, India's arrival in the international arena as a rapidly growing economy has been entirely due to liberalization of the economy and space provided to the private sector to expand. The 'animal spirits' it unleashed, and the institutional reforms that aided accumulation and competition, helped private capital, so long leashed by regulation, to lead the economy. In their view, the inefficiency of the state-owned enterprises and the resources they wasted were partly responsible for India's poor growth and investment record. The unfinished agenda, according to this folklore, is to further dismantle and dismember the public sector, especially the SOEs (Bhagawati \& Srinivasan 1993; Bhandari \& Goswami 2000).

This folklore ignores the significant role played by SOEs in India's emergence as a successful and growing economy. To examine the role of the SOEs in the Indian economy, we need to review their impact on the goals that the Indian elite set for itself: namely, to accelerate the rate of investment and growth to double digits and to imitate, if not exceed, China's record. What has been the contribution of SOEs to the key props of this growth acceleration? Are they relatively inefficient as compared to the private sector enterprises, with lower productivity and returns on capital employed?

Section 1 above has shown us that the public sector as a whole had substantially reduced its investment in the economy. Is this true of CSOEs too? What role have SOEs performed in the accelerating investment and accumulation in India? We see from Table 3 that the CSOEs 


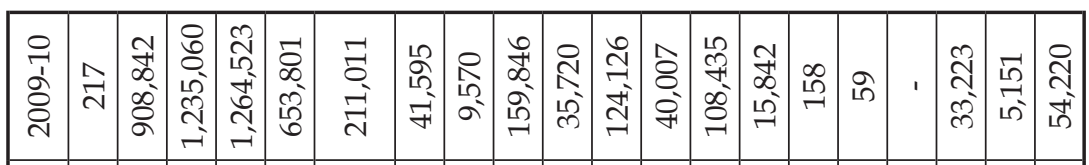

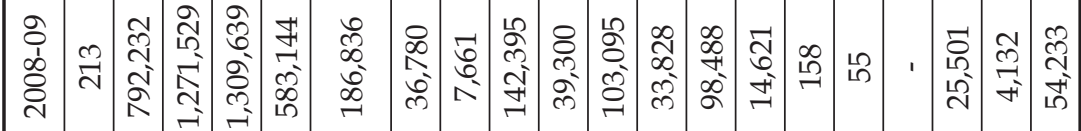

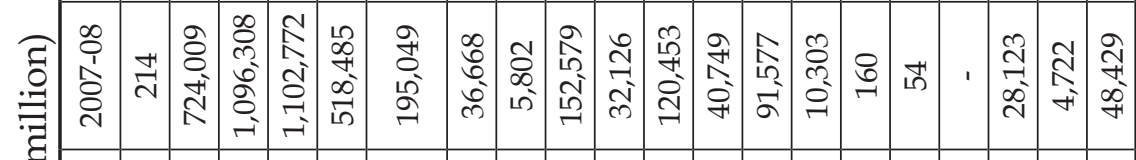

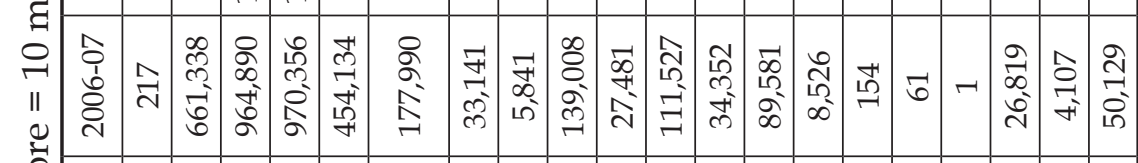

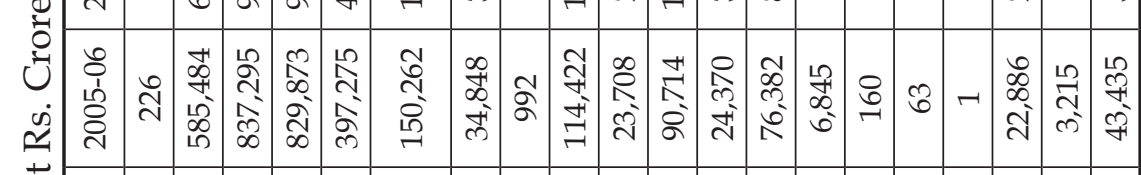$$
\text { 节舟 }
$$

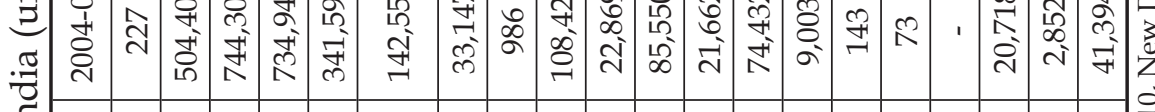$$
\text { E }
$$

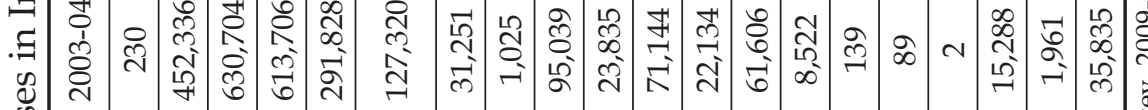$$
\text { है: }
$$

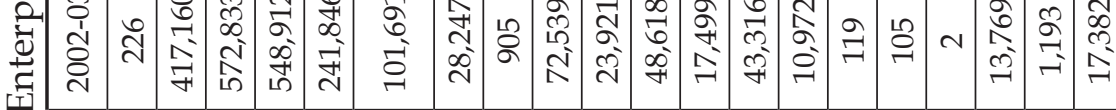

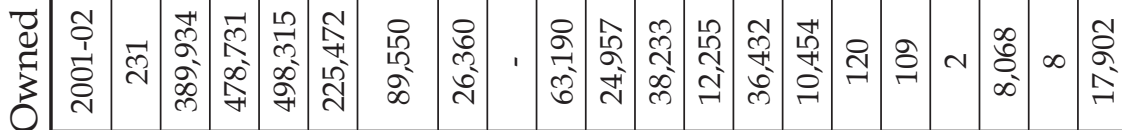

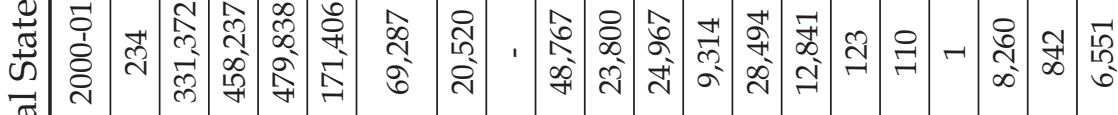

\begin{tabular}{|c|c|c|c|c|c|c|c|c|c|c|c|c|c|c|c|c|c|c|c|}
\hline 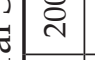 & & m & 号 & 字 & $\stackrel{\lambda}{\curvearrowright}$ & ( & $\vec{N}$ & & & & & & & & & & & & \\
\hline 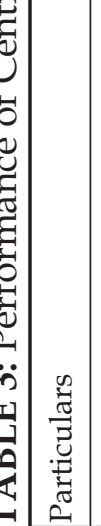 & 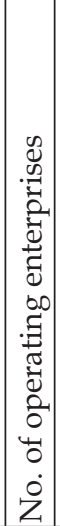 & 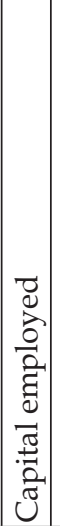 & 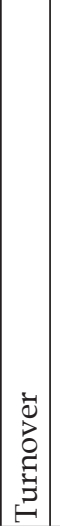 & 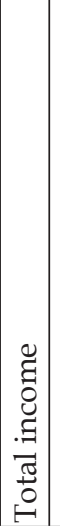 & 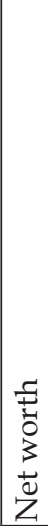 & 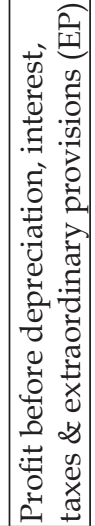 & 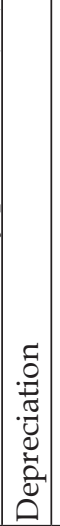 & 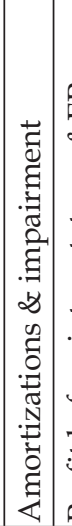 & 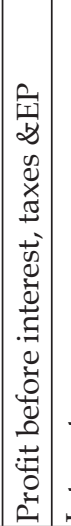 & 崩 & 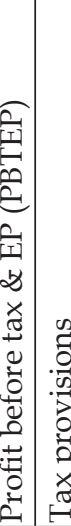 & 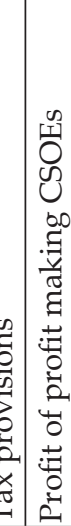 & 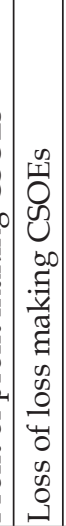 & 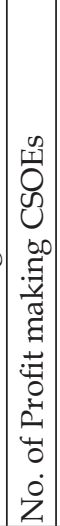 & 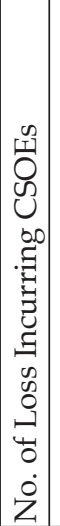 & 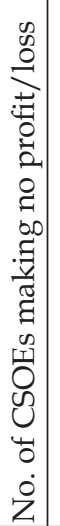 & 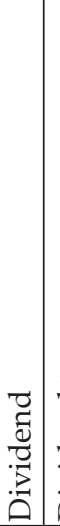 & 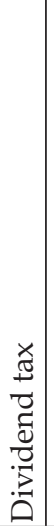 & 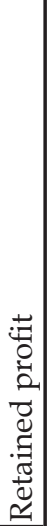 \\
\hline
\end{tabular}


have significantly enhanced their internal dividends, most which go to the central government. Has this increased payout sapped their capacity to invest?

We begin with a stylized overview of the SOEs in India. For this we use data from National Account Statistics (NAS) for savings and investment. The data on CSOEs is collected and provided annually by the Department of Public Enterprises in Public Enterprise Surveys. The 'Non-Departmental Undertakings', which we call SOEs here, are registered as 'companies' under the (Indian) Companies Act and follow similar disclosure and accounting practices as the private firms. ${ }^{4}$ This provides for the possibility of a comparison of the performance of 'companies' by ownership, for which databases that provide data on all companies registered under the Companies Act, whether listed or unlisted on stock exchanges, are useful. We use data from the Prowess database maintained by the Centre for Monitoring Indian Economy (CMIE) for a comparative analysis.

Like China, SOEs in India are controlled by the central (federal) government (CSOEs) and by the state (provincial) governments (SSOEs), with few controlled by city municipalities. The SOEs controlled by the provincial (state) government, called SSOEs here, are controlled by respective provincial (state) governments. However, though there are about 838 SSOEs with investment above Rs. 2.7 trillion (compared to only 249 CSOEs with investment of Rs. 9 trillion), their role in the growth story (with the exception of a few states) has been marginal (India 2007a). Two thirds of the investment of SSOEs is concentrated in electricity generation and distribution, with the rest spread unevenly in manufacturing, finance and infrastructure (India 2007a). The political economy of electricity pricing, with subsidized or free electricity to farmers and other favoured sections, with no clear budgetary support for these, has undermined SSOEs and their viability.

Figure 1 shows the relative share of SSOEs and CSOEs based not on Public Enterprise Surveys, but on the Prowess database. Of the total SOEs in the Prowess database, CSOEs (controlled by the central government) have a dominant share. As Figure 1 shows, about 80-90 per cent of all SOE assets are accounted for by the 217 CSOEs. The SOEs controlled by the state (provincial) governments, have a small though increasing share. Part of the reason for the small decline in CSOEs' share (from 90 per cent to about 80 per cent) is due to the privatization of a few large SOEs by the BJP-headed government during the 2000-2003 period. 
FIGURE 1: Relative Size of Central and State SOES

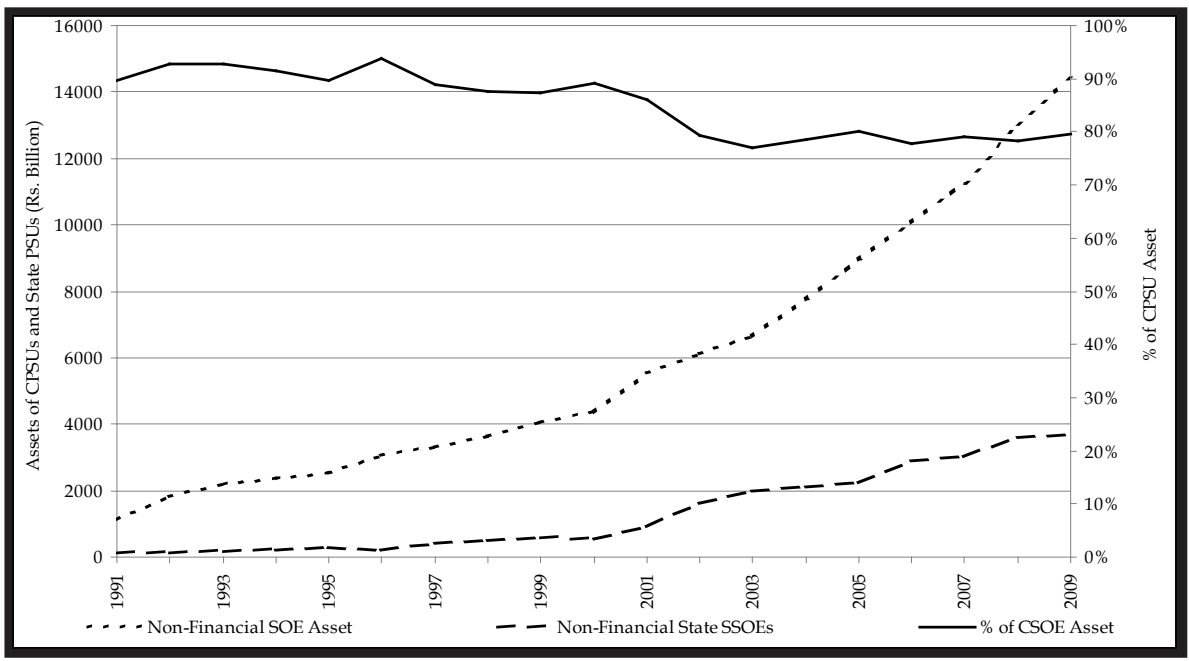

Source: Our analysis from Prowess Database, from Centre for Monitoring Indian Economy (CMIE), Sept. 2011

The SOEs, though incorporated as companies, until 1990 were largely not listed on stock exchanges and the entire equity of most SOEs was held by central or state governments. ${ }^{5}$ As they are all registered under the Companies Act, or similar statutes (e.g., state electricity boards), all the CSOEs and SSOEs are part of what is called the 'corporate sector'.

As mentioned, although a few SOEs were privatized by the BJP government, the majority have remained in the public sector. Thanks to the governance reforms in the public sector and greater commercial autonomy to most enterprises, the better-performing CSOEs today enjoy greater autonomy, are listed on the Indian stock exchanges and have independent directors on board. Have these changes made any difference to their efficiency, productivity, their growth and expansion or their role in the economy?

To answer this, it is important to analyze the actual performance and the changing and enhanced role of SOEs in the economy. The public sector has historically been the driver of economic growth in the Indian economy. From the period of the Second Five-Year Plan (1956), the public sector has accounted for about $45-50$ per cent of gross capital formation (Table 1).

Section 1 above and Tables 1 and 2 reflect the changes in the Indian savings and investment ratios during the last two decades. The recent acceleration of the economic growth rates in India - from about 6 per cent per annum during 1992-2003 to about 8-10 per cent recently - are largely explained by rising domestic savings and investment (Mohanty 
\& Reddy 2010). The domestic savings and investment rate rose from about $18-20$ per cent in the 1980 s to about $22-25$ per cent in the $1990 \mathrm{~s}$ and further, to about 33-35 per cent, since 2004. Over the entire period of deregulation and reforms (1991-2010), foreign savings or FDI have played a minor role. ${ }^{6}$

The CSOEs have an important role in the economy, and despite opening up most sectors to private players, most industrial CSOEs have continued their growth and expansion. Contrary to the conclusion of declining savings and investment, at least the CSOEs have improved their performance and increased their rate of investment. The decline is entirely due to sharp reduction in savings by 'public authorities', whose large dis-savings have eroded the contribution of SOEs.

The key feature of the new regime beginning in 1991 has been the expansion of the capital markets and associated accumulation in the private corporate sector. Though SOEs, too, have begun to tap the expanding bond and equity markets, by and large, the sale of their equity has been to generate revenue for the central government. What is more, with increasing profitability of SOEs, a large part of the accelerating investment also has been largely internally financed.

FIGURE 2: Manufacturing Assets by Ownership Group (in Rs. crore)

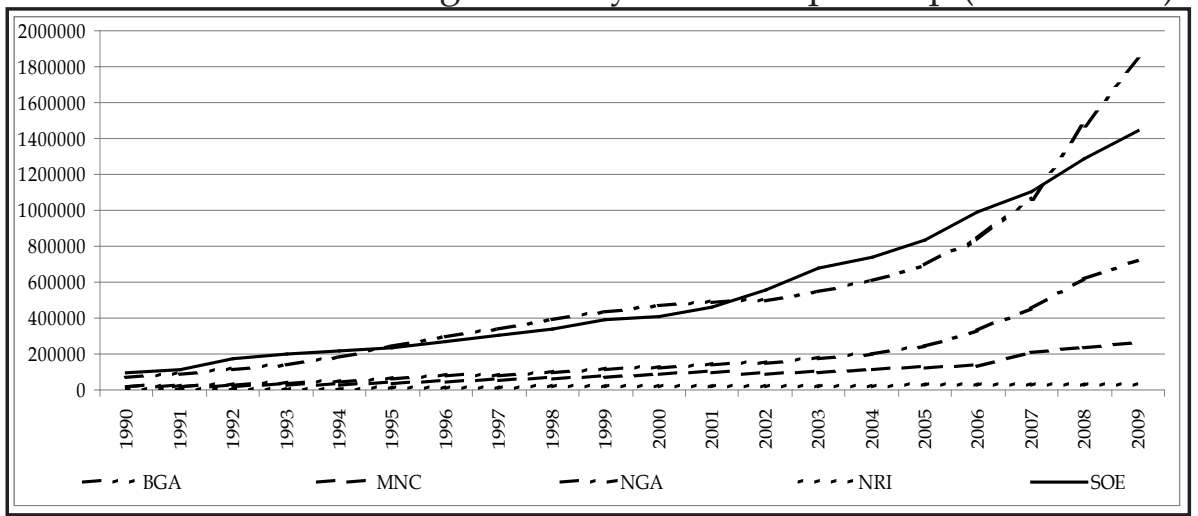

Notes: BGA = Business Groups; MNC= Foreign Owned ; NGA = Private Independent Firms; NRI

$=$ Non Resident Indians; $\mathrm{SOE}=$ State Owned Enterprises; 1 Crore $=10$ Million rupees

Source: Our analysis from Prowess Database, from Centre for Monitoring Indian Economy

Using the data from the Prowess database, Figures 2 and 3 show the assets controlled by different ownership groups in Indian manufacturing and services (other than financial companies). The ownership groups we have chosen are the SOEs (both controlled by central and state (provincial) governments), while the private sector is divided into business groups (BGAs) or families whose conglomerates dominate the Indian private sector, non-family-controlled independent firms (NGA) and the 
FIGURE 3: Service Industries Assets by Ownership Group (in Rs. crore)

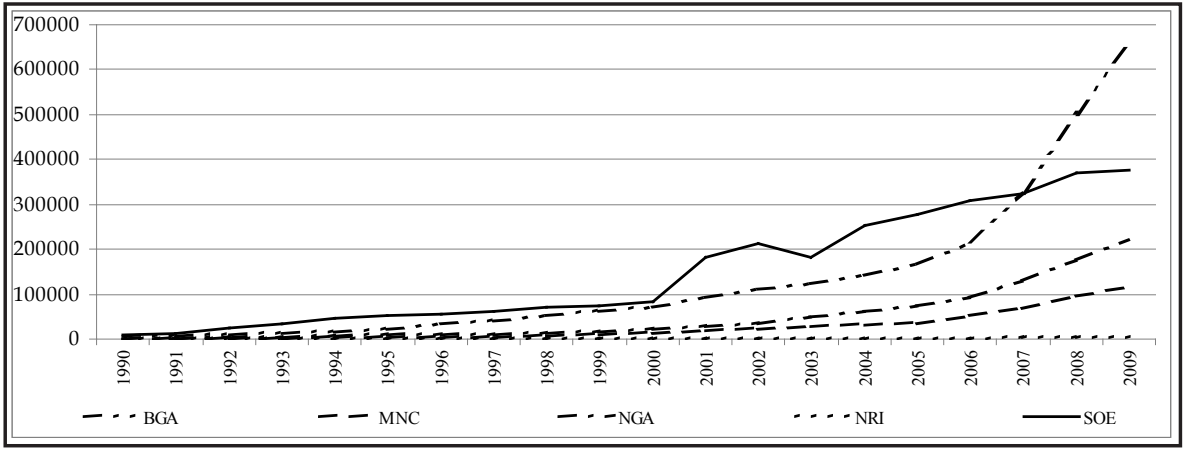

Notes: BGA = Business Groups; MNC= Foreign Owned ; NGA = Private Independent Firms; NRI = Non Resident Indians; SOE $=$ State Owned Enterprises; 1 Crore $=10$ Million rupees Source: Our analysis from Prowess Database, from Centre for Monitoring Indian Economy

foreign-controlled firms (MNC and NRI), divided into firms controlled by multinational companies and non-resident Indians.

It is clear from the two figures that SOEs in India have kept pace with the accumulation and investment in the private corporate sector, both in the manufacturing as well as the services sector. Their share of total assets has changed only marginally until the recent period. We could conclude that they have played an important if not the pivotal role in the expansion of investment and output.

In the manufacturing sector, the SOEs' assets exceeded all other groups up to 2006, when the large business groups overtook the SOEs in terms of total assets controlled by them. What is more significant, despite a government decision to reduce budgetary support to CSOEs, the SOEs continued accumulation at a faster pace than before. This was partly due to increasing savings and investment rates in the economy, especially from 2000-2001, and increasing savings of the SOEs from internal resources (see Table 3 above).

However, Figure 2 shows that since 2007, assets controlled by Indian business groups (BGA) have accelerated and overtaken the total assets of SOEs. This we suspect is due to several large acquisitions by a few Indian business groups abroad. Thus, the Tatas acquired Corus Steel in a deal valued at US\$ 12 billion, and acquired Jaguar and Daewoo's commercial vehicle business, besides acquisitions in Indonesia and South Africa in steel and mines. Similarly, large-scale acquisitions have been made in aluminium by the Aditya Birla group, in coal and minerals by the Vedanta and Adani groups, and in telecommunications by the Bharati group. Since 2007, the outward FDI from India has matched or 
exceeded inward FDI. This may have altered the balance between SOEs and business groups.

However, if the assets controlled by SOEs are inefficiently used, as many economists argue, (see Bhagwati \& Srinvasan 1993; Bhandari \& Goswami 2000; Seabright 1993), the SOEs may actually be a drag on the Indian economy. In the absence of SOEs or their full-scale privatization, the rate of growth as well as accumulation may have been faster!

In order to answer this argument, we need to address the issue of efficiency of resource use by SOEs, vis-a-vis private sector firms. Since CSOEs represent the bulk of SOEs' investment and are the main players in the Indian economy, we focus the following analysis only on them. The first thing to note is that the number of such enterprises is miniscule (only 217) compared to several thousand SOEs in China. Secondly, they are limited in their scope and confined largely to the sectors reserved for them by the Industrial Policy of 1956.Thirdly, about one fourth of CSOEs constitute sick private sector firms that were abandoned by their private owners, and were subsequently nationalized to protect jobs and investment.

Table 3 above, using data from Public Enterprise Surveys (PES) ${ }^{7}$ shows the profile of central government SOEs during the last 10 years. As can be seen from the table, the number of loss-making enterprises has fallen from 110 to 55-58 and their losses have been contained at Rs. 12-14 billion. This is largely due to the financial restructuring carried out at the recommendation of the Board for Reconstruction of Public Sector Enterprises and strengthening of their management teams.

The profit-making CSOEs have shown exemplary performance during this decade. While their capital employed has jumped 274 per cent (from Rs. 3,313 billion to Rs. 9,088 billion) their profits after tax have risen by 380 per cent (from Rs. 284 billion to Rs. 1,084 billion) and their dividends by 402 per cent (from Rs. 82 billion to Rs. 332 billion). What is more significant, the retained profits have increased by 827 per cent (from Rs. 65 billion to Rs. 542 billion) (Table 3). These profits are despite the price controls on several commodities manufactured and sold by CSOEs, the most significant of which are the petroleum refining and marketing companies. The government has not allowed the CSOEs in the petroleum sector to increase prices of petrol, LPG and diesel in line with the increase in the price of crude oil. Similarly, prices of fertilisers manufactured by CSOEs have been controlled to provide subsidized inputs to farmers. All these populist price controls have substantially lowered the combined profits of CSOEs. 
To answer the questions about their efficiency and use of resources, we need to compare their performance with those of the private sector. We leave out the state-owned banks and financial services firms, which have been separately studied by several scholars, the most well known being the study by Ram Mohan (2005).

For a comparison of private and state-owned enterprises, we use data from the Prowess database, which covers the entire corporate sector (including CSOEs, SSOEs and private sector firms). From Prowess, we have estimated the change in assets as a proxy for investment (presented in Figure 4). As Figure 4 shows, all SOEs (including SSOEs controlled by provincial governments) contributed about 30 to 70 per cent of all corporate sector investment in the economy during the last decade. This was during a period when the overall investment rate in the economy rose from 25 per cent to 35-37 per cent.

To compare the efficiency of private and public sector firms, we have used the Prowess data, with some filtering. The Prowess database has data on 13,019 firms in the manufacturing private sector and 234 SOE firms in

FIGURE 4: Share of Corporate Sector Investment by Ownership

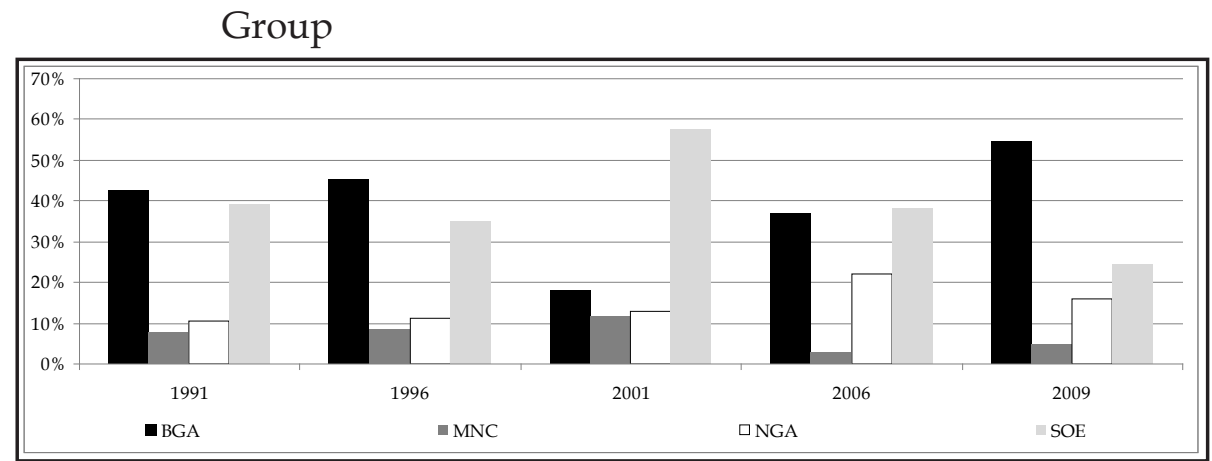

Source: Our estimates from CMIE Prowess Database

the manufacturing public sector. Similarly, it has data on 6,759 firms in the services private sector and $118 \mathrm{SOE}$ firms in the services public sector. For our analysis, we selected firms with a total income over Rs. 1 billion. Moreover, we ignored firms where one or more data point was missing. Longitudinal data covering a 20-year period (1991-2011) was collected. As the Prowess database has added new firms over the years, the number of firms with sales of more than Rs. 1 billion each year varies. ${ }^{8}$

As the Figures 5 and 6 clearly show, with reforms and empowered boards, manufacturing CSOEs with sales of above Rs. 1 billion (US $\$ 25$ million), substantially improved their performance and through marketdriven pricing were able to match the private sector's return on capital 
FIGURE 5: Manufacturing Firms: Return on Capital Employed (Private firms and SOEs)

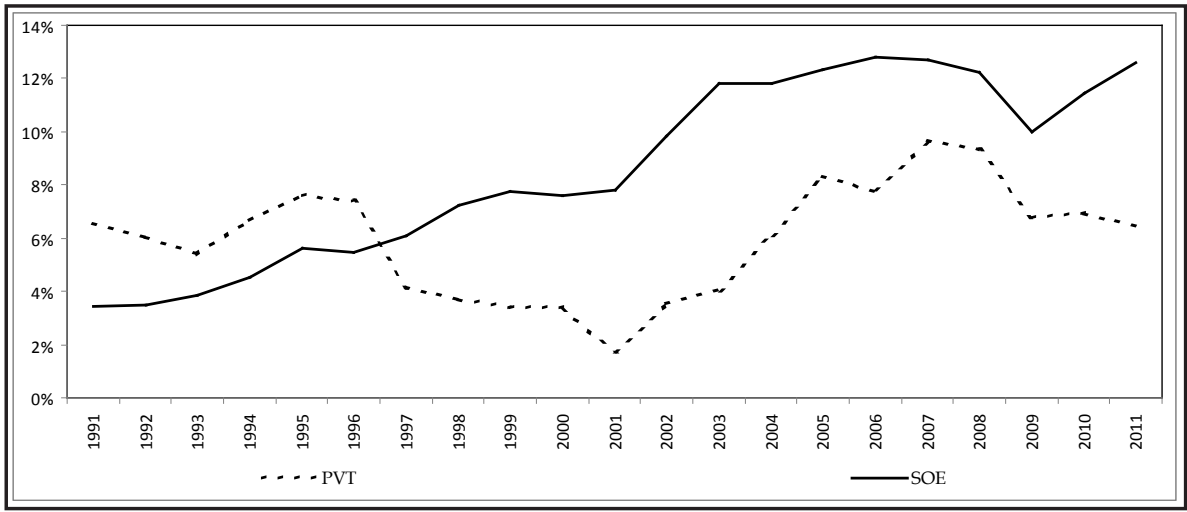

Source: Computed from Prowess data, Centre for Monitoring Indian Economy

by the second half of the 1990s. Thereafter, their performance has been superior to private firms in resource use. As Figure 6 shows, only the foreign-owned private firms enjoy returns that are close to (but lower than) those of CSOEs. Other segments of private firms, namely Indianowned independent firms (NGA) and business group-controlled firms (BGA) had far lower returns.

The picture in the services sector is different. Service sector CSOEs had lower returns on capital employed, and with pricing reforms and cuts in subsidies, were able to raise their profitability to levels equal to the private sector by the turn of the century. However, SOEs such as Air India and the telecom firm BSNL, have found it difficult to meet the competition or shed workers (for example, BSNL has 100,000 employees that are estimated as 'surplus') and are incurring large losses. Both

FIGURE 6: Return on Capital Employed (by Ownership Group)

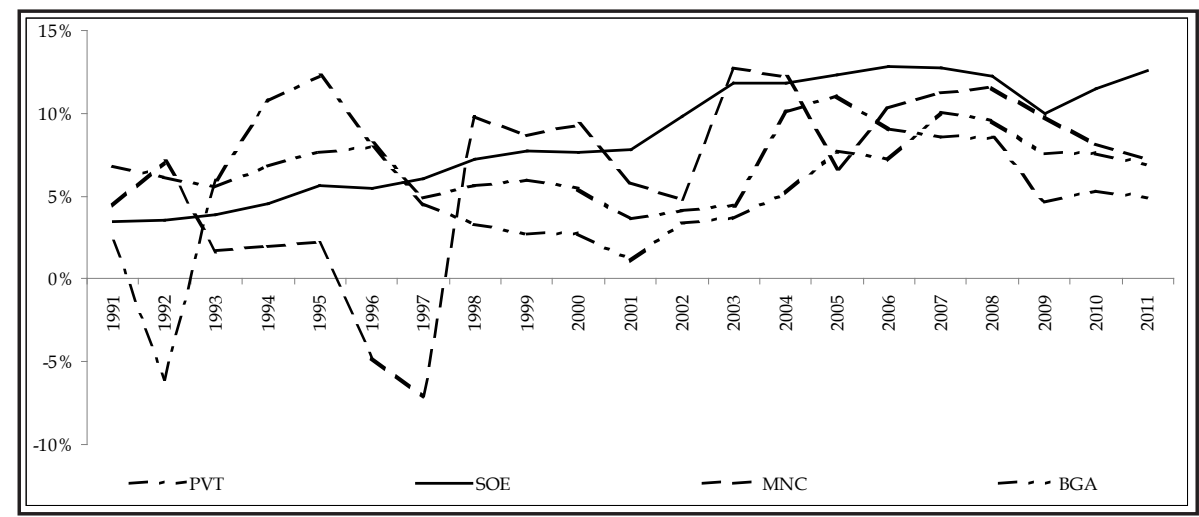

Notes: PVT=Private independent firms; SOE=State-owned enterprises; MNC= Foreign-owned firms; $B G A=$ Business groups 
FIGURE 7: Service Industry Firms: Return on Capital Employed (Private Firms and SOEs)

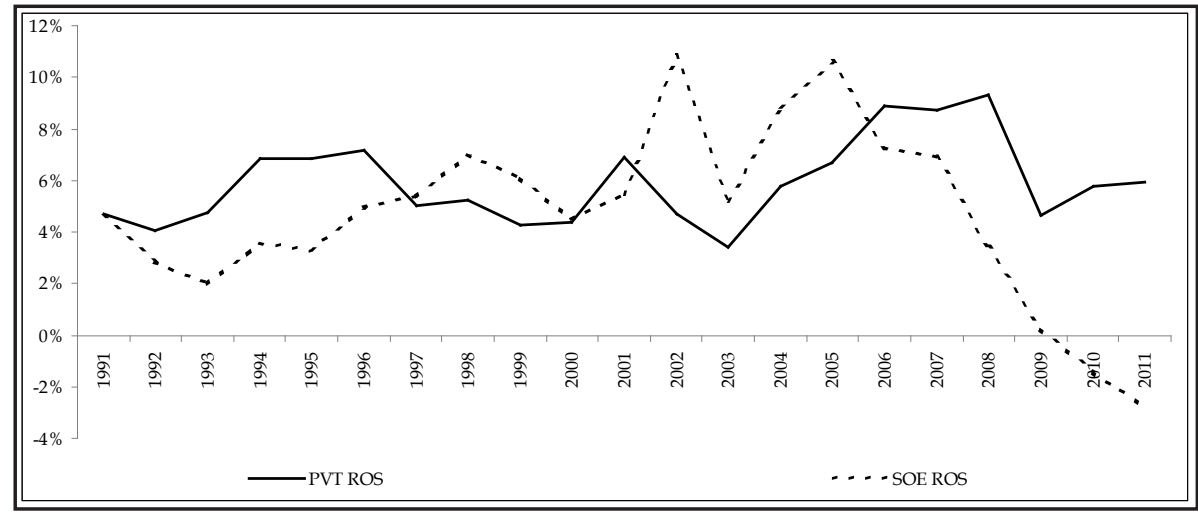

FIGURE 8: Service Industry Firms: Return on Capital Employed (by Ownership Group)

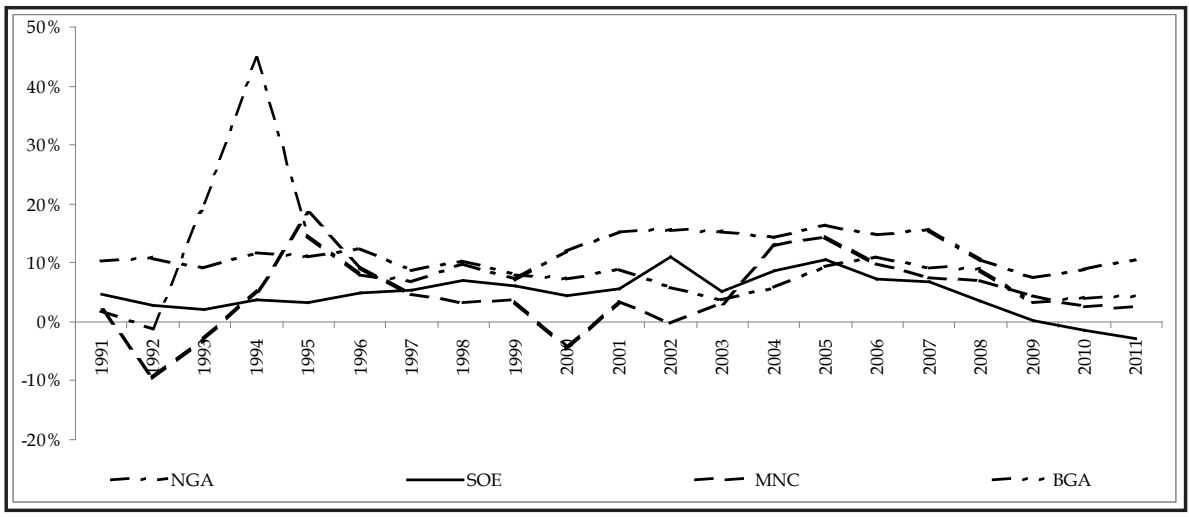

these industries have seen excess supply and hyper-competition, with declining prices, which has eroded their ability to respond. Large losses in the airline and telecommunication sectors after 2004 have lowered the return for the group as a whole.

In addition, we must keep in mind that several CSOEs in the services sector are actually promotional firms, such as the Tourism Development Corporation and the North East Export Promotion Corporation. They are meant to develop infrastructure to crowd in private investment or to help small firms access markets and resources.

Thus, there is no conclusive proof that CSOEs are grossly inefficient and unprofitable. With reforms aimed at strengthening autonomy and decision making, the manufacturing SOEs actually out-perform the private sector firms. Several CSOEs are now listed and have emerged 
as champions on the Indian stock exchanges and account for 25-30 per cent of market capitalization of the entire Indian capital market. They also enjoy excellent credit ratings in the global bond markets and have several large foreign institutions as their important investors.

\section{Conclusion}

Economic reforms and shifts in public policy towards market-based reforms and an end to protection and reservations provided to SOEs, along with the imminent threat of privatization, have posed serious challenges to SOEs in India. Increasing competition and the entry of the private sector in most industries reserved for SOEs, along with liberal imports, provided the impetus for reform and the shift in their corporate strategy.

Opposition to full-scale privatization shifted the government's strategy from using SOEs to generate resources to demanding enhanced dividends and listing them on the stock markets, with small sales of equity. On the other hand, the government agreed to provide them with greater autonomy and improve corporate governance by changing the composition of their boards and enhancing the powers of these boards for investment and strategic decisions. Though these reforms were limited to better-performing SOEs, they partially changed the relationship between the ministries and the enterprises. Simultaneously, under pressure from the communist parties, on whose support the Congress Party government was dependent, limited restructuring of sick SOEs was carried out. It helped about 40 sick enterprises to emerge as profitable and competitive units.

But theSOEs' major role has been in supporting and expanding the industrial base in the country. SOEs account for about 30 per cent of all corporate sector investment. They have kept pace with the increasing investment rate. The CSOEs, which are controlled by the central government, account for about 7 per cent of total gross capital formation in India.

During the last decade, the rate of profitability of SOEs has doubled and in the manufacturing sector is now superior to private sector enterprises. In services, their performance has been poorer, which can be largely attributed to losses in airline and land-line telecommunication firms. They account for a significant share of the market capitalization on the National Stock Exchange.

The recent surge in GDP growth rates in India is largely explained by the increasing investment. Though the central government has found 
it difficult to maintain its historical share in total investment due to its rising fiscal deficits, the CSOEs have not only maintained their share, but marginally increased it.

This is quite like the picture in China, where the SOEs have been the major site of investment and accumulation. However, unlike in China, the Indian SOEs face a policy environment that assumes that private capital is more efficient and where a large private sector is able to successfully influence public policy in its favour, sometimes through lobbies and on other occasions through direct bribes. The scandals in the telecom sector under investigation are a potent example.

Sushil Khanna is Professor of Economics and Strategic Management at the Indian Institute of Management Calcutta. His areas of research interest include: India's economic reforms and transformation, public sector, corporate governance and global expansion of Indian firms.

\section{NOTES}

1 The Voluntary Retirement Scheme in Indian SOEs was entirely voluntary. If employees refused to accept the severance package and continued their employment contract, they would be retrenched. However, the salaries and wages in loss-making SOEs were not revised. Many skilled workers, who could find jobs in the private sector, left the SOEs.

2 By 2008 there were five 'Maha-Ratnas' (Great Jewels) with power to invest up to Rs. 50 billion, 16 'Nav Ratnas' (New Jewels) with power to invest up to Rs. 25 billion, and 66 'Mini-Ratnas' (Small Jewels) with lower powers. See Indian Department of Public Enterprises website at http:/ / dpe.nic.in/ newsite/navmini.htm.

3 For example, in February 2003, a speaker from the global consulting firm Deloitte noted a 'growing political opposition to privatization in emerging markets due to widespread perception that it does not serve the interests of the population at large', which it attributed to a number of features of privatization: 'Pressures to increase tariffs and cut off non-payers; loss of jobs of vocal union members that will be hard to retrain; [and] the perception that only special interests are served - privatization is seen as serving oligarchic domestic and foreign interests that profit at the expense of the country ...'. (Hall, Lobina \& de la Motte 2005: 287-288). India was part of the survey.

4 This is in contrast to China, where company law and corporatization of SOEs is a recent phenomenon, since 1994.

5 Few private companies that were nationalized did have small private equity held by individuals, and insurance companies.

6 Since 2005, the inflow of foreign investment has accelerated and the current account deficit has widened to between 2 and 3 per cent of GDP, reflecting greater reliance on foreign savings.

7 The Public Enterprise Surveys (PES) data excludes any data or comparison with privately owned enterprises. 
8 The number of firms used for analysis varies as shown in the table below:

\begin{tabular}{|l|l|c|c|c|c|c|}
\hline \multicolumn{2}{|l|}{ Year } & 1991 & 1996 & 2001 & 2006 & 2011 \\
\hline \multirow{3}{*}{ Manufacturing } & Private & 65 & 141 & 223 & 383 & 439 \\
\cline { 2 - 7 } & Public & 14 & 37 & 37 & 43 & 42 \\
\hline \multirow{2}{*}{ Services } & Private & 23 & 99 & 210 & 413 & 495 \\
\cline { 2 - 7 } & Public & 14 & 23 & 33 & 42 & 35 \\
\hline
\end{tabular}

\section{REFERENCES}

Bhagwati, J. N., and T. N. Srinivasan. 1993. India's Economic Reforms, New Delhi: Ministry of Finance.

Bhandari, L., and O. Goswami. 2000. 'So Many Lost Years: The Public Sector Before and After Reforms'. New Delhi: NCAER.

Chattopadhyay, R. 1987. 'An Early British Government Initiative in the Genesis of Indian Planning'. Economic and Political Weekly 22(5).

Hall, D., E. Lobina, and R. de la Motte. 2005. 'Public resistance to privatization in water and energy'. Development in Practice 15(3 \& 4).

India, Government of. 1993. Report of the Committee on the Disinvestment of Shares in PSES (Rangarajan Committee), April. New Delhi.

India, Government of. 1997. Disinvestment Commission, Report I, February. New Delhi.

India, Government of. 2005. Report of Ad Hoc Group of Experts on Empowerment of CPSEs (Arjun Sengupta Committee), April. New Delhi: Ministry of Heavy Industries and Public Enterprises. Available from: http:/ / dpe.nic.in/publications/report_of_ad_ hoc_group_of_experts_on_empowerment_of_cpses.

India, Government of. 2007a. National Survey on State Level Public Enterprises, 2006-07. New Delhi: DPE.

India, Government of. 2007b. 'White Paper on Disinvestment of Central Public Sector Enterprises'. New Delhi: Department of Disinvestment.

India, Government of. 2011. Public Enterprises Survey 2009-10. New Delhi.

Mohanty, M., and N. Reddy. 2010. 'Some Explorations into India's Post-Independence Growth Process, 1950/51-2002/03: The Demand Side'. Economic and Political Weekly 45(41).

Ram Mohan, T. T. 2005. Privatization in India: Challenging the Economic Orthodoxy. New Delhi: RoutledgeCurzon.

Seabright, P. 1993. 'Infrastructure and Industrial Policy in South Asia: Achieving the Transition to a New Regulatory Environment'. Washington, D.C.: World Bank. 